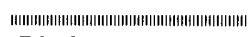

論丈レビュー

\section{知覚と意識における神経回路の協同現象と バインディング}

\section{はじめに}

本文は，神経回路の動的バインディングの機能とそ の意識機構に扔ける役割についての研究をエンゲル氏 (Andreas K. Engel) がまとめたレビュー1)を概説す るものである，氏は視覚を中心に神経回路の協同現象 (コヒーレントダイナミクス) の研究を手掛けており, ジンガーやグレイの共同研究者としても良く知られて いる.

本レビューでエンゲルはいくつかの生体の実験の例 を引用しながら, 時間バインディング, 即ち神経細胞 集団のミリ秒スケールの同期発火が広く, 意識や注意 機構, ワーキングメモリー等の高次機能の基本要素で あるという自説を展開しており, 神経回路のモデリン グの見地からも興味深い. また意識活動に関わる神経 活動が, 主に $20 \mathrm{~Hz}$ 以上のガンマ带の同期発火とし て現われ，これが脳の総合的な働きに深く関わってい ることも取り上げている。

\section{センサリー・アウェアネスとは}

まず，本レビューの原題にも用いられている，セン サリー・アウェアネス（sensory awareness）という 言葉について簡単に説明したい.クリックとコッホは 視覚的アウェアネスを提唱したが, これはセンサリ 一・アウェアネスの一種であり，意識にのぼる視覚体 験と一般に説明される.クリックによると脳は多くの 情報を受容し並行処理しているが，そのうち，前頭前 野に投射する領野の活動のみがアウェアネスとして意 識によって経験されるのだという2).

一方エンゲルは，意識は通常捉え所の無いものだ が，意識の核をなす部分の一つであるセンサリー・ア ウェアネスは神経回路の機構としてモデリングでき, 実験による定量的評価が可能と考えた。例えば広く受 け入れられている仮説として，何らかのアウェアネス (気づき) が脳内で生じるためには必要条件として以 下の 4 段階, 即ち, 意識の前段階である覚醒状態, 感 党情報のセグメンテーション, 知覚の選択機構（注意 機構), ワーキングメモリー,の 4 つの機能が必要で あるが，これらは特定の神経細胞群の協同活動によっ て実現することができると主張している，以下見てみ よう.

\section{バインディング問題〜知覚の統合}

アウェアネスのためには，脳内の知覚情報を適宜統 合する機構が必要である。脳内の素の情報は色や動き といったモダリティの各機能部位に広く分散している ため, ある知覚対象が意識の元に読み出される (Read-out）ためには，知覚を構成する素情報が皮質 間で適切に束ねられるような機構が必要である。これ はバインディング問題と呼ばれるが，神経細胞の同期 的発火（時間的バインディング）という概念を用いる とスマートに解決できる。即ち，皮質間に分散した特 徵を表現するニューロンがタイミングを同期して発火 し，それによって各特徵が統合されるとするのであ る.

感覚情報のセグメンテーションにおいても，同様に ある種のバインディング機構が必要である。例として 視覚情報を考えてみると, 線分や端点といつた並列処 理される信号のうち，何らかの方法で対象のオブジェ クトを構成する情報のみを切り出して高次の領域に送 らねばならない。ここで同期的発火を使えば，オブジ エクトに属す素情報のニューロンだけが同期的に発火 し，それ以外のノイズや無関係な線分といったニュー ロンは同期しないという形でセグメンテーションを考 えることができる，実際に麻酔下のネコと覚醒状態の サルの視覚野では, 同方向に動く $2 つ 0$ 線刺激に対応 する2つのニューロンの発火の相関は高く, 動く方向 が異なると相関が消失することが観測されている. 注 意したいのはニューロンの発火頻度自体に変化は無 くニューロン間の相関発火のみが生じたり消えたり することである.セグメンテーションは，ニューロン のポピュレーションや発火頻度によって表現される特 徴の信号をダイナミックなバインディングに変換する 作業だと言える。

知覚を統合する機序としてエレガントな仮説である 時間的バインディングだが，クリックとコッホによる と, 高次の選択的注意の機構やワーキングメモリーも バインディングによる持続的な同期状態によって説明 できるようである。注意下にある対象のニューロン群 (ニューロンアセンブリー）如同期してる間リズミッ クに脱分極・過分極を促される、脳のどこかに短期記 憶を実現している反響回路があると想定すると，同期 的振動を積極的に用いて記憶回路へアセンブリーの信 号を転送することによって選択的注意やワーキングメ モリーが実現されているのではないかと考えられるの である。またバインディングによる同期発火は $10 \sim 20$ ミリ秒という短い時間スケールであることが 知られているが，これはシナプスの前後でLTPと 
LTDの変化を起こすのに必要な時間空に当たり,こ の点も短期記憶におけるバインディング機能の役割を 示していて興味深い.

ところで，相関発火が皮質間で伝達されるためには 入力を受けつける側に神経発火のコインシデンスを検 知するニューロンが必要である。通常，生体が外界か ら受ける刺激の対象は複数である。例として，右から 飛んでくる赤いボールと上から飛んでくる緑のボール といったような複数のモダリティが交錯せずに皮質間 でやりとりされなくてはいけない，そう考えると，脳 領域上に離れたニューロン間で，伝達時間にノイズ幅 がある皮筫間通信を経て複数のアセンブリーが正確な 同期信号を維持できるかどうか，神経回路モデルの立 場から慎重な検証を要する部分であろう。推測になる が，ニューロンが単体でなくアセンブリーとしてリズ ミックな振動発火をし，引きこみ現象を利用すること で正確なタイミングを補償しているのかもしれない。

では次に実際にこれらアウェアネスに関わるバイン ディング機構を支持する生理学的な見地のいくつかを 見てみよう。

\section{諸 研 究}

\section{・各脳領域におけるニューロンの同期現象}

エンゲルは本論文以前の関連研究を俯瞰して, どの 生物種のどの脳領域のニューロンに同期発火が見られ るのか示した。实に，霊長類，げっ歯類，鳥類，爬虫 類, 昆虫, と多くの種の, 視覚, 聴覚, 嗅覚, 運動, 記憶，身体感覚，と殆どの脳領域内のニューロンにお いて普遍的に $20 \mathrm{~Hz}$ 以上，多くは20〜 $50 \mathrm{~Hz}$ の スぺ クトルを持ったガンマ帯と呼ばれる周期の拢動発火が 存在し，ニューロン群はこのガンマ波によってシンク 口発火を行っていることが確認できた。またどの種に おいても 10〜20ミリ秒と極短い久ケールの時間空の 中でバインディングされていることが判っている。こ こで言う時間空とは，信号がこれよりもずれると同期 から外れてしまうという同期の正確さを意味してい る。このような同期発火は生体において普遍的な現象 であると言える。

\section{・両眼視野闘争}

視覚的アウェアネスを説明するのに有名な実験に両 眼視野闘争がある。被験者の目に片目ずつ別々に移動 方向の異なる格子模様を見せ続けると，被験者の目の 前に架空の格子模様の境界が生じ，それが勝手に動的 に変化するように見える。両眼の網膜や初期視覚野の 知覚に変化が生じたのではないため，これは高次の脳 領域で視覚情報を文脈的に選択するアウェアネスが動 的に変化して生じている現象であることが判る.
ネコでこの実験を行い，神経活動を観測した研究を 見てみよう3”。視覚野のニューロンのうち，それぞれ 右の視野からの刺激を受ける二ューロンペアと左の視 野から受けるニューロンペアで相互相関を計測した。 まず片目ずつ単一模様の格子を見せた状態で神経活動 を計測すると，格子模様に対してバインディングが生 じて，ぞちらのぺアとも，ガンマ帯の振動を持った高 い相関の同期発火が見られる. 次に両眼に別々の格子 を見せて競合を起こさせる．やはり正の相互相関が生 じるのだが, 高次のアウェアネスの変化に伴い, 右の ペアの相関が増えると左の相関が減り，その逆が起こ ったりという競合的な関係が見られるようになる。こ れによりガンマ帯の時間的バインディングの増減はア ウェアネスと密接な関係を持っていると考えることが できる。

\section{・人間の意識活動におけるコヒーレンス}

人間に扔いて時間的バインディングの働きは，脳波 や脳磁睬上のガンマ帯の脳波成分として観測すること ができる．多くの実験で，被験者がタスクを行ってる 問，特定の部位で特定のガンマ带の周波数の同期が見 られ，タスクの処理に伴って同期が増減することが確 かめられている。

ワーキングメモリーとガンマ帯の同期発火について 調べた研究4では，視覚刺激による遅延見本合わせ課 題を行うと前頭前野と後頭部の間に 25 60 Hz の周 波数带の同期が見られ，作業の段階に応じて同期発火 の周波数成分が細かく変化した。タスク実行時に見ら 机るこのような高い周波数成分は麻酔時と深い睡眠時 には消失することからも，バインディングが何らかの 意識活動の機序となっている可能性は高い.

\section{結論と考察}

以上を踏まえ，エンゲルの仮説を交えてどのような ダイナミクスが脸内で起こってるかまとめよう。まず 知覚された情報はバインディングによって動的にセグ メンテーションされる．このセグメンテーションは刺 激依存で決定するのでなく，トップダウンな文脈にも 依存する相互作用である。次に対象に関係するニュー ロンアセンブリーが文脈的に選択されて他の脳領域と リンクされ，その総体として注意機構が生じる。また 適宜バインディングされた信号が反響回路に転送され て保持されることで，ワーキングメモリーが実現す る.

また感覚情報が文脈的に統合される段階で，脳に階 層的な構造があることも強調しておきたい．下層の情 報がより上層の時空間的な文脈として繰りこまれると いう入れ子構造であり，脳の多くの皮質の領野間にこ 
のような階層的な様式が存在することが解剖学的に判 っている。脳は、上述のような特徵のバインディングを 各段階で繰り返して脳内に大域的なコヒーレンスを形 成して複雑な情報を統合していると考えられる。

但し注意したいのは，大域的コヒーレンスといって も皮質間が一様な同期振動でバインディングされてい る状態ではないことである。てんかんの発作や深い睡 眠時に脳に一齐の同期振動が見られることがあるが， この現象とは全く異なる。実際の脳のコヒーレンスは 広い領域に渡りながら, 非定常であり, 生じるバイン ディングの周波数領域も多岐に渡る。

これを踏まえ，エンゲルは各階層での統合様式とし て多重伝送的な信号でリンキングが行われているので はないかという仮説を述べているが,これも興味深 い.

(慶應大学 舘 俊太)

1) Engel, A. K. and Singer, W. (2001): Temporal binding and the neural correlates of sensory awareness, Trends in Cognitive Sciences, Vol. 5, No. 1

2) Crick, F. and Koch, C. (1990): Towards a neurobiological theory of consciousness, Semin. Neurosci., Vol. 2, pp. 263-275

3) Fries, P., Roelfsema, P. R., Engel, A. K., Konig, P. and Singer, W. (1997) : Synchronization of oscillatory responses in visual cortex correlates with perception in interocular rivalry, Proc. Natl. Acad. Sci. USA,Vol. 94, pp. 12699-12704

4) Tallon-Baudry, C., Bertrand, O., Peronnet, F. and Pernier, J. (1998) : Induced $\gamma$-band activity during the delay of a visual short-term memory task in humans, J. Neurosci., Vol. 18, pp. 4244-4254

\section{ブレインウェブ：位相同期と長距離にわたる} 統合過程

外界情報の知覚, 感情, 期待, 考㝋などは, 脳内に 広く分散する神経活動として表現される。認知，行動 のサイクルの流れの中で, 長距離にわたって分散する 神経活動は，時及刻久選択され，統合され，再編され なければならない，最近の実験の知見に基づき，この ような長距離にわたる動的リンクを実現する機構の候 補として, Varela ら ${ }^{1)} は$ 多重な周波数带域が関与卞 る同期（synchronization）を提案しており，ここに 紹介する.Varela らは，位相固定が脳の統合の実体 であるとの仮定に基づき，信号から位相と振幅とを分 離し，位相の同期（phase synchronization）を調べ る必要性を強調している。また，脳の同期現象の特徵 として過渡的な性質に注目している。一連の認知過程 において，生成した位相同期ネットワークは，新たな
別の同期ネットワークに向けて，一旦崩壊する. Varelaらは，いくつかの㥶験の知見に基づいて,こ の崩壊過程への能動的な位相脱同期（phase scattering）の関与を示唆している。このような動的なネッ トワーク形成は，コンピュータネットワークのウェブ を連想させ，総説の表題にあるブレインウェブは，著 者らの脳の同期ネットワークに対する視点を表してい る.以下，さらに踏み込んでV Varelaらの総説を解説 する。

Varela らは，同期が成立する空間スケールを2つ に大別している１つは，1 cm 以下の距離にわたる 局所的な同期であり，皮質力ラム内 $(<2 \mathrm{~mm})$, 視覚 皮質内のカラム間 $(2-7 \mathrm{~mm})$, Brodmann の 17 野と 18 野との間 $(1 \mathrm{~mm})$ での同期が例として紹介されて いる.この同期は，主に双方向性の単シナプス結合に より成立している，局所的な同期は，各々の感覚情報 が一旦断片化されたのち局所回路における内部表現と して再構成される過程に関与すると考えられる。例え ば, 視覚の結合問題との関わりが議論され, 多くの研 究がなされてきた。しかし，Varelaらがこの総説で 注目するのは， $1 \mathrm{~cm}$ 以上の長距離氾わたる同期であ る. 長距離の同期は，入力された多くの感覚情報と感 情，期待といった内部情報との統合に関わり，認知を 支える基本原理と考えられる，遠く隔たった局所神経 回路間の相互作用は，双方向性の多シナプス結合によ り媒介される。例えば, 前頭葉と後頭葉あるいは雨半 球にまたがる結合の場合, パルス伝達の時間遅れは数 十 mseck及ぶが，同期状態は数百 $\mathrm{msec}$ 程度持続 し，相互作用が可能である。ボトムアップとトップダ ウンとの同時的な神経活動を支持する実験的証拠を引 用しながら，長距離の同期を支える神経機構として， 双方向性結合の重要性を強調している.

同期を検出するために，任意の $2 つ の$ 電極から導出 された LFP (local field potential), 頭皮上での EEG (electroencephalogram), MEG (magnetoencephalogram）信号の関係を調べる.これらの信号は, 方向性を持った樹状笑起群でのシナプス後電位であ り，局所的な神経集団への他領域からのパルス入力を 反映した活動である.多くの研究では，2つの信号の 相互相関係数を求め, コヒーレンスを定義する方法が 用いられてきた。この場合，コヒーレンスが高まった 状態が同期と呼ばれてきた。総説に引用されたほとん どの研究においても，この方法が用いられている。こ れに対して，すでに述べた通り，Varelaらは位相の 同期に注目する重要性を指摘している．信号から位相 と振幅とを分離し，各サンプリング点での瞬時位相を 